Pilkov Kostiantyn,

$\mathrm{PhD}$ (Law Sciences),

Justice at Supreme Court (Ukraine), Kyiv National University of Trade and Economics, 19, Kyoto str., Kyiv, 02156, Ukraine ORCID: 0000-0002-8931-0413

Researcher ID: M-3878-2016

\title{
JURISPRUDENCE AND INSTITUTIONAL CHANGES IN ADJUDICATION OF COPYRIGHT INFRINGEMENT CASES IN UKRAINE
}

Due to the judicial reform in Ukraine the system of adjudication of copyright infringement cases as well as the jurisprudence in these matters changes dramatically. The system of courts having jurisdiction over copyright infringement cases is expected to change soon. Also, the newly reformed Supreme Court has made some changes in jurisprudence in copyright infringement cases recently. Both of these aspects of the reform (institutional aspect and new trends in the court practice) are going to be discussed in this article with the main focus on the institutional reforms in Section I of this article, and Section II to be devoted to changes in jurisprudence made by the Supreme Court. Particular attention is going to be paid to some recent developments in court practice related to measuring damages in copyright infringement cases and problems courts are facing while dealing with online copyright infringements.

Keywords: copyright infringement cases, IP court, online copyright infringements.

Пільков Костянтин. Іінституційні зміни у судовій практиці розгляду справ про порушення авторських прав.

У зв'язку з судовою реформою в Украӥні різко змінюється система розгляду справ про порушення авторських прав, а також судова практика в цих питаннях. Очікується, що система судів, які мають юрисдикиію у справах про порушення авторських прав, незабаром зміниться. Також нещодавно реформований Верховний Суд нещодавно вніс зміни в практику судочинства щодо порушення авторських прав. Обидва ці аспекти реформи (інституиійний аспект та нові тендениії судової практики) будуть обговорені в цій статті з основним акиентом на інституиіональні реформи в розділі I статті, а розділ II буде присвячений змінам судової практики, винесених Верховним Судом. Особлива увага буде приділена деяким останнім подіям у судовій практиці, пов'язаних 
з вимірюванням збитків у справах про порущення авторських прав, та проблемами, з якими стикаються суди під час роботи з порушеннями авторських прав в Інтернеті.

Ключові слова: справи про порушення авторських прав, IP-суд, порушення авторських прав в Інтернеті.

Relevance of research topic. Ukraine is currently dealing with major reforms, of which the judicial reform is probably the most essential and complex. It started in 2016, went through several phases of 'rebooting' of main institutions of the judicial branch, and recently has come to the stage where specialized courts must be established, one of those is the High Court for Intellectual Property. Thus, the system of courts having jurisdiction over copyright infringement cases is expected to change in 2019 and 2020. Apart from that institutional component of the reform, the newly reformed Supreme Court has made some changes in jurisprudence in copyright infringement cases recently.

Formulation of the problem. The major institutional and jurisprudential changes related to adjudication of copyright infringement cases need to be discussed in details, and viewed in connection with the general trend of reforming national system of copyright protection and its approximation to the standards applied according to the TRIPS Agreement and EU-Ukraine Association Agreement.

Analysis of recent researches and publications. Theoretical and practical aspect or reforming courts adjudicating IP cases are widely discussed. Studies on advantages and disadvantages of specialized IP courts have been conducted recently in many countries facing that challenge. Among articles and reports on this problematic topic we should mention papers prepared by Jacques de Werra, Rohazar Wati Zuallcobley, Denis Borges Barbosa and Pedro Marcos Nunes Barbosa, Hong Xue, Shamnad Basheer and Susan Isiko Štrba. Among Ukrainian authors, A. Butyrskiy studied the specialization principle within the Ukrainian court system, and O. Stoiev analyzed the benefits of specialized IP courts for Ukraine (Stoiev, 2015), while O. Iavorska presented a well-grounded critics of the concept of IP courts in Ukraine (Iavorska, 2018). Recent papers by A.Shtefan and K. Zerov deserve attention as the ones focused on legislative and jurisprudential developments of protection of copyright in Internet (Zerov, 2016).

Presenting main material. Currently, common courts (civil jurisdiction) and commercial courts (commercial jurisdiction) have the jurisdiction over copyright infringement cases. The delimitation of jurisdictions is mostly parties-based. However, after the judicial reform enters its further stage when the High Court for Intellectual Property (the ' $H C I P$ ') starts functioning, copyright infringement cases will be subjected to its jurisdiction. Although this step is sometimes heavily criticized (Iavorska, 2018) it is also viewed also as a step forward in reforming the system of 
adjudication of IP cases (Zerov, 2016; Vardamatska, 2017) in particular towards predictable jurisprudence ${ }^{1}$.

I. COURTS HAVING JURISDICTION OVER COPYRIGHT INFRINGEMENT CASES

\section{A. Current hierarchy of courts}

Civil copyright infringement cases (involving at least one private individual not being registered as a sole entrepreneur as a claimant or respondent) are under jurisdiction of common courts:

1. District courts as courts of first instance;

2. Courts of appeals;

3. Supreme Court (its Civil Cassation Court having no specialized chamber and its Grand Chamber in limited cases, e.g. conflict of jurisdiction, necessity of unification of court practice of different courts of cassation, cases having fundamental importance for the development of the law).

Commercial copyright infringement cases (mainly those in which only legal entities and sole entrepreneurs participate) are under the jurisdiction of commercial courts:

1. Local commercial courts in regions;

2. Commercial courts of appeals having jurisdiction over several regions;

3. Supreme Court (its Commercial Cassation Court having the chamber specialized in IP matters and its Grand Chamber).

\section{B. Specialized IP court}

In 2019-2020, copyright infringement cases will be subjected to the jurisdiction of the HCIP as the court of first instance. The court will be located in Kyiv and it will consist of twenty-one judges (President of Ukraine, Decree No. 299/2017).

The jurisdiction of the HCIP is defined in the Code of Commercial Procedures (the ' $C C P$ ') new version of which was adopted on October 3, 2017 (16) and entered into force on December 15, 2017 except for some provisions including those related to jurisdiction of the HCIP, they will enter into force when the HCIP starts working.

Article 20(2) of the CCP lists the following matters to be subjected to jurisdiction of the HCIP as soon as it officially starts functioning (the delimitation of jurisdictions is based on the subject matter criterion):

${ }^{1}$ It is also expected that the HCIP will publish landmark cases on its website which is to be created in 2019. Up until now the Unified Register of Court Decisions (access available at $\mathrm{http}$ ://reyestr.court.gov.ua/) is the only official database in which decisions of every court in Ukraine are stored and made available to the public since 2007. Users can specify in their searching requests category of the case («commercial» or «civil») and then choose the subcategory («IP related case»). For court decisions issued after January 1, 2019 users can find within the category of IP related cases further division and chose cases «regarding copyright» and «regarding related rights». However, no separate and publicly available database of court judgments in IP cases apart from the Register exists in Ukraine. 
- Intellectual property rights to inventions, utility models, industrial designs, trademarks, business names and other IP rights, including the right of prior use;

- Registration and keeping records of IP rights, the invalidation, prolongation and early termination of patents, certificates and other acts certifying IP rights or violating such rights or lawful interests associated with them;

- Deciding whether a trademark is well-known;

- Copyright and related rights, including disputes concerning the collective management of copyright and related rights;

- Concluding, amending, terminating and executing agreements for IP rights management and franchising agreements; and

- Protection against unfair competition such as unlawful usage of a trademark or a product by another manufacturer; copying the outer appearance of a product; collecting, disclosing and using commercial secrets; judicial review of the decisions by the Antimonopoly Committee of Ukraine in the abovementioned cases.

Thus, the hierarchy of courts having jurisdiction over copyright infringement cases is going to be the following:

1. HCIP as the court of first instance;

2. Appeal chamber within the HCIP;

3. Supreme Court as the court of cassation (specialized chamber in IP cases).

This new hierarchy is already facing some harsh critique, in particular for having an appeal court within the same institution that adjudicates the disputes as a court of first instance (Iavorska, 2018).

II. CHANGES IN JURISPRUDENCE IN COPYRIGHT INFRINGEMENT CASES

A. Calculation of damages in civil (commercial) procedures for copyright infringement cases

There is no standard approach as to what circumstances have to be taken into account while calculating and awarding damages in copyright infringement cases in Ukrainian civil and commercial procedures. Courts usually take into account all relevant aspects, such as the negative economic consequences, including lost profits, which the injured party has suffered, any unfair profits made by the infringer or steps taken to obtain such profits, other economic and non-economic factors. Because proving the causal link from violation to particular amount of damages may become problematic, the rightholders often claim for an alternative remedy - statutory damages.

In 2018, the Ukrainian Law on Copyright and Related Rights (the 'Copyright Act') (Zakon Ukrainy «Pro avtors'ke pravo i sumizhni prava») was amended to introduce new approaches towards enforcement of IP rights, specified in EU-Ukraine Association Agreement. According to Article 240 (1)(b) of the Association Agreement Ukraine took the obligation to ensure that when the judicial authorities set damages they are able in appropriate cases, as an alternative to setting actual damages to set the 
damages as a lump sum on the basis of elements such as at least the amount of royalties or fees which would have been due if the infringer had requested authorisation to use the intellectual property right in question.

Before the respective amendments entered into force, the Copyright Act provided the owners with alternative of claiming actually suffered damages - claiming a lump sum, most recently in range of UAH18,410 (approximately USD 660) to UAH 92,050,000 (approximately USD 3,400,000). This remedy was very popular among claimants because it did not require the precise amount of damages to be proven. As shown by recent jurisprudence, courts usually applied close to minimal amount of the above statutory damages (up to UAH 32,000) for a single violation. Courts usually considered as a single violation of IP rights the unlawful use of each work if several works were used. Also the use of each particular copy of a work and each separate manner of using a work might be considered as a single violation. Supreme Court usually upheld that approach (Supreme Court (Ukraine), Resolution of March 6, 2018; Supreme Court (Ukraine), Resolution of May 21, 2018).

Since July 22, 2018, after the above amendments to the Copyright Act entered into force, the lump sum has to be calculated based on the license fee the infringer would have paid to obtain the rightsholder's permission (actually, as its double amount or, in case of an intentional violation, triple amount of the license fee).

B. Provisional measures in copyright infringement cases

In 2003, the Ukrainian procedural laws were essentially transformed to satisfy the requirements set in Article 50 of the TRIPS Agreement (Agreement on TradeRelated Aspects of Intellectual Property Rights). Similar requirements were set in EU-Ukraine Association Agreement (Article 236) (Association Agreement, 2014). In view of the coming change in the system of courts having jurisdiction over copyright infringement cases and subjecting these cases to the jurisdiction of the HCIP which will conduct proceedings according to the Code of Commercial Proceedings (the $"$ 'CCP') in this article we focus on the provisional measures that might be established according to the CCP.

There are two types of provisional measures the courts may take:

1. Measures aimed at securing enforcement of the court decision if issued in favor of a claimant - interlocutory injunctions (Section I Subsection 10 of the CCP):

- seizure of property and (or) money, belonging to or due to the respondent;

- prohibition to take particular actions by the respondent;

- prohibition to take particular actions with respect to the matter in dispute or transfer money or property to the respondent or perform any obligation to the respondent by a third party;

- stopping of customs clearance procedures with respect to goods or objects that contain IP rights;

- other measures that are not explicitly specified in the procedural law, but can secure effective defense or restoration of violated rights. 
2. Measures aimed at securing evidence ( $§ 8$ of Section I Subsection 5 of the CCP):

- examination of a witness;

- appointing expert examination;

- court order to produce and (or) inspect evidence;

- prohibition of particular actions as to the evidence or ordering a person to commit particular actions with respect to the evidence.

These measures, if taken before the claim is submitted, are to be taken by the court having jurisdiction over the district where the evidence is located or where necessary procedural actions need to be taken. Otherwise it is for the court that is considering the case to decide on these measures.

Motions for both types of measures can be filed with the respective court before the claim is submitted, simultaneously with filling of the claim or in the course of proceedings. The court may take these measures without the respondent having been heard (ex parte), in particular where any delay would cause loss or difficulties in production of the evidence. Interlocutory injunctions aimed at securing enforcement of the court decision are usually taken ex parte.

The court is obliged to decide on the motion for securing measures within 5 days after its delivery to the court, 2 days - in case of a motion for interlocutory injunctions. Among other requirements the motion has to explain the necessity of taking the requested measures and be paid with the fee. If an applicant obtained provisional measures (court issued respective ruling) and failed to submit the claim within 10 days or the claim was rejected by the court, the court shall revoke the measures the next day after the said term elapsed or the claim rejected.

For both types of measures the court has the right to order the applicant to provide a security or equivalent assurance sufficient to protect the respondent and to prevent abuse.

\section{Cross-border IP infringement cases}

In court practice related to cross-border IP infringements three topics are still among those that are lively discussed: jurisdiction, applicable law, and recognition and enforcement of foreign judgments.

a) Applicable law. The principle of territoriality limits the effects of an intellectual property right to the country of its protection. Thus Ukrainian substantial law is applicable if the country in which the act of infringement was committed where the protection is sought is Ukraine (lex loci protectionis) according to Article 37 of the Law of Ukraine «On Private International Law» (Zakon Ukrainy «Pro mizhnarodne pryvatne pravo», 2005), which entered into force on September 1, 2005. Parties' choice of law is not permitted in cases of IP infringements, i.e. in non-contractual relations. In contrast to that the contracts regarding IP rights can be governed by the law chosen according to general rules of determining the applicable law in contractual relations. 
b) Jurisdiction. Ukrainian courts find themselves competent and having jurisdiction over the IP infringement cases in which the alleged violations took place in Ukraine and the person who allegedly violated the IP rights is officially registered in Ukraine (Resolution of the Supreme Court of April 25, 2018 in «Microsoft Corporation v. Zhytomyrgaz PJSC» ${ }^{2}$ (case No. 906/353/17): although the Supreme Court remanded this case, so that it was sent to the lower court, this case clearly illustrates that the commercial court properly recognized jurisdiction over the dispute about the alleged violation of copyright to the software produced in the USA and the rightholder was the entity incorporated in Washington, USA (Supreme Court (Ukraine), Resolution of April 25, 2018). Also Resolution of the Supreme Court (Commercial Cassation Court) of March 13, 2018 (case No. 918/186/17 «NGO RC Social Partnership v. Ecology Investments LLC») (Supreme Court (Ukraine), Resolution of March 13, 2018) presented below in Subsection D of this Section in details).

c) Recognition and enforcement of foreign judgments. Ukrainian courts recognize and enforce foreign judgments if an effective international treaty on recognition and enforcement of judgments exists between Ukraine and the state where the judgment was rendered ${ }^{3}$, or on foot of reciprocity. Reciprocity is presumed to exist unless otherwise is proven as it has been recently reiterated by the Supreme Courts in its Resolution of October 31, 2018 (case No. 127/10583/17) (Supreme Court (Ukraine), Resolution of October 31, 2018).

D. Jurisprudence in online copyright infringement cases

In several recent decisions the Supreme Court gave some directions for further development of jurisprudence in online infringement cases by issuing conclusions on important issues of jurisdiction and admissibility of evidence in such cases.

a) «Uploading movie clips on Facebook: jurisdiction and evidentiary mattersı: Resolution of the Supreme Court (Commercial Cassation Court) of March 13, 2018 (case No. 918/186/17 «NGO RC Social Partnership v. Ecology Investments LLC») (Supreme Court (Ukraine), Resolution of March 13, 2018): In this case the courts found that the registration details of the Respondent contained among other information also the address of the official website of that entity. The website had a

${ }^{2}$ The name of the case is given for convenience only. Court cases are formally indentified only with their unique numbers.

${ }^{3}$ Ukraine is a party to over 35 bilateral treaties on legal assistance in civil matters, which contain provisions about recognition and enforcement of judgments. However, the majority of those treaties are not directly applicable to judgments in commercial disputes. Ukraine is also a party to several multilateral agreements directly or indirectly regulating the enforcement of foreign judgments. Some of these cover the Commonwealth of Independent States (CIS), e.g. Kyiv Agreement on Settlement of Commercial Disputes of 1992 and Minsk Convention on Legal Assistance and Legal Relations in Civil, Family and Criminal Matters of 1993. One of the most widely used international multilateral instruments to which Ukraine is a party is HCCH Convention on Civil Procedure of 1954. 
link to the Facebook profile of that legal entity where a short movie clip had been uploaded. The copyright to that movie clip belonged to the Claimant.

This case is important for several reasons:

i. Courts found admissible as evidence of the content of the Respondent's website and its Facebook profile the report issued by an independent IT-firm, which is neither an expert institution nor an entity formally authorized to certify such facts;

ii. Courts reviewed the content of webpages directly at the hearing and admitted the screenshots of those webpages as additional evidence. Until recently courts were reluctant to conduct fact-finding researches of the Internet and assign any evidentiary value to the results of any such research. Sometimes notarized reports of the content of webpages or expert opinions were admitted as the only relevant, admissible and reliable evidence. The fact that the Supreme Court upheld the decisions of the lower courts in this case may be a sign that the jurisprudence develops towards less formal approach with regard to evidence;

iii. The lower courts and the Supreme Court did not get involved into the theoretical discussion about whether posting a movie on the Facebook page constitutes a display of a work and whether the copy that was made available for access constituted a copy of the work as the law defined it. The Supreme Court only concluded that the use of the work (public display) took place and it was not the noncommercial use, which was permitted by the law under certain conditions;

iv. The Supreme Court also upheld the opinion of the lower courts about the jurisdiction over the dispute. As the Resondent's Facebook page was available for access from anywhere in Ukraine, and the Claimant presented evidence (report of the independent IT firm issued in one of the regions) of the infringement in a particular region (where the report was issued), the local commercial court found that it had jurisdiction over the case as the infringement allegedly took place in its district. It was a simple solution to a significant theoretical questions of where an online infringement of IP rights actually took place and which court has the jurisdiction over the dispute.

b) «Uploading copyrighted materials on a website: evidentiary matters»: Resolution of the Supreme Court (Commercial Cassation Court) of March 13, 2018 (case No. 910/7092/16 «Universe Media Corporation LLC» v. Interactive Marketing LLC») (Supreme Court (Ukraine), Resolution of March 13, 2018): the Supreme Court upheld the opinion of the lower courts that the Respondent infringed the Claimant's IP rights to a movie by uploading and thus making it available on the website belonging to the Respondent (the Respondent was registered as the owner of the domain name). The courts also took progressive approach towards admissibility of evidence and admitted the minutes of the commission which was established according to the Claimant's order to inspect the content of the respective webpage as well as the video in which the inspection was filmed.

Conclusion. Although the Supreme Court has recently adopted some progressive approaches to determining whether the publishing a work online may be 
considered as a public display or performance or sharing copies of the work, and thus constitute a violation of the copyright, Ukrainian jurisprudence is expecting the more sophisticated debate as it is clear that the above forms of use are not the same.

The development of modern technologies of sharing and distributing information, such as torrent sharing of pieces of files that may not be used by a human without computer technologies, may bring another set of legal questions as to what constitutes sharing copies of the work. These problems already became a hot topic among scholars, though the courts have not addressed these issues. Also the issues related to jurisdiction my rise again with respect to posting copyrighted materials on websites to which the access of some users is limited or restricted.

After the 2018 amendments to the Copyright Act changed the approach towards calculating statutory damages Ukrainian courts may face problems in deciding on the fair amount of hypothetical license fees that now constitute the basis for calculating lump sums alternative to damages. Courts also have to decide on the guilt of the respondent and apply tripled amount of the fee when they find the violation was intentional.

Apart from the challenges raised by 2018 amendments, the members of the judiciary are constantly facing the important questions of what material can be admitted as evidence (Pilkov, 2014, p. 149) and what probative value should it be assigned with in IP cases, especially when the line between the technical field or any other area where the expert knowledge is required and the common sense where the judge can made a competent opinion about the facts is not clear. The current trend towards wide use of the procedural economy and effectiveness principle in court proceedings combined with the judicial reform which may soon bring Ukraine the functioning specialized court in IP matters (HCIP), shows the direction of the development of the jurisprudence away from rigid adherence to use of expert opinions when deciding on many important questions in IP cases.

\section{REFERENCES}

1. Agreement on Trade-Related Aspects of Intellectual Property Rights (TRIPS). Retrieved from https://www.wto.org/english/docs_e/legal_e/27-trips_03_e.htm

2. Association Agreement between the European Union and the European Atomic Energy Community and their member states, of the one part, and Ukraine, of the other part, Signed 21 March 2014. Official Journal of the European Union. L 161/3. 29.5.2014 Retrieved from https://trade.ec.europa.eu/doclib/docs/2016/ november/tradoc_155103.pdf

3. Iavorska, O. (2018). Ukraine's new High Intellectual Property Court: implications for the justice system. Briefing Paper 91. April 2018. 6 p. Retrieved from https://democracy-reporting.org/wp-content/uploads/2018/05/DRI-BP-IPCourt.pdf 
4. Pilkov, K. (2014). Evidence in International Arbitration: Criteria for Admission and Evaluation. The International Journal of Arbitration, Mediation and Dispute Management. Vol. 80. No. 2. P. 147-155.

5. President of Ukraine, Decree No. 299/2017 «On the Establishment of the High Court for Intellectual Property» Retrieved from http://zakon2.rada.gov.ua/ laws/show/299/2017 [in Ukrainian].

6. Stoiev, O. (2015). Ukraine: Specialised Approach to Intellectual Property Within the Courts - 5 Reasons to Accept. Socialiniu mokslu studijos, Vol 7, No 1. P. 173-184. DOI:10.13165/SMS-15-7-1-12

7. Supreme Court (Ukraine), Resolution of April 25, 2018 (case No. 906/353/17) Retrieved from http://reyestr.court.gov.ua/Review/73699874 [in Ukrainian].

8. Supreme Court (Ukraine), Resolution of March 13, 2018 (case No. 918/186/17). Retrieved from http://reyestr.court.gov.ua/Review/72763168 [in Ukrainian].

9. Supreme Court (Ukraine), Resolution of March 13, 2018 (case No. 910/7092/16). Retrieved from http://reyestr.court.gov.ua/Review/72764578 [in Ukrainian].

10. Supreme Court (Ukraine), Resolution of March 6, 2018 (case No. 922/1448/17). Retrieved from http://reyestr.court.gov.ua/Review/72730741 [in Ukrainian].

11. Supreme Court (Ukraine), Resolution of May 21, 2018 (case No. 924/290/17). Retrieved from http://reyestr.court.gov.ua/Review/74221207 [in Ukrainian].

12. Supreme Court (Ukraine), Resolution of October 31, 2018 (case No. 127/10583/17). Retrieved from http://reyestr.court.gov.ua/Review/77763384 [in Ukrainian].

13. Vardamatska, O. (2017). Coming IP Courts: the Devil is in the Procedure. The Ukrainian Journal of Business Law. No. 5. Retrieved from http://www.ujbl.info/ article.php?id $=946$

14. Zakon Ukrainy «Pro avtors'ke pravo i sumizhni prava» № 3792-XII vid 23.12.1993 [Law of Ukraine «On Copyright and Related Rights»]. Retrieved from https://zakon.rada.gov.ua/laws/show/3792-12 [in Ukrainian].

15. Zakon Ukrainy «Pro mizhnarodne pryvatne pravo» № 2709-IV vid 23.06.2005 [Law of Ukraine «On Private International Law»]. Retrieved from https://zakon.rada.gov.ua/laws/show/2709-15 [in Ukrainian].

16. Zakon Ukrainy «Pro vnesennya zmin do Hospodarskoho protsesualnoho kodeksu Ukrayiny, Tsyvilnoho protsesualnoho kodeksu Ukrayiny, Kodeksu administratyvnoho sudochynstva Ukrayiny ta inshykh zakonodavchykh aktiv» № 2147-VIII vid 03.10.2017 [Law of Ukraine «On Amendments to the Commercial Code of Procedure of Ukraine, Civil Code of Procedure of Ukraine, Administrative Code of Procedure of Ukraine and other Laws»]. Retrieved from https://zakon.rada.gov.ua/ laws/show/2147-viii [in Ukrainian].

17. Zerov, K. (2016). Reproduction of work posted on Internet by end-user: practice of the European Union and Ukrainian prospects. Visegrad journal on human rights. No. 1. P. 111-115. 